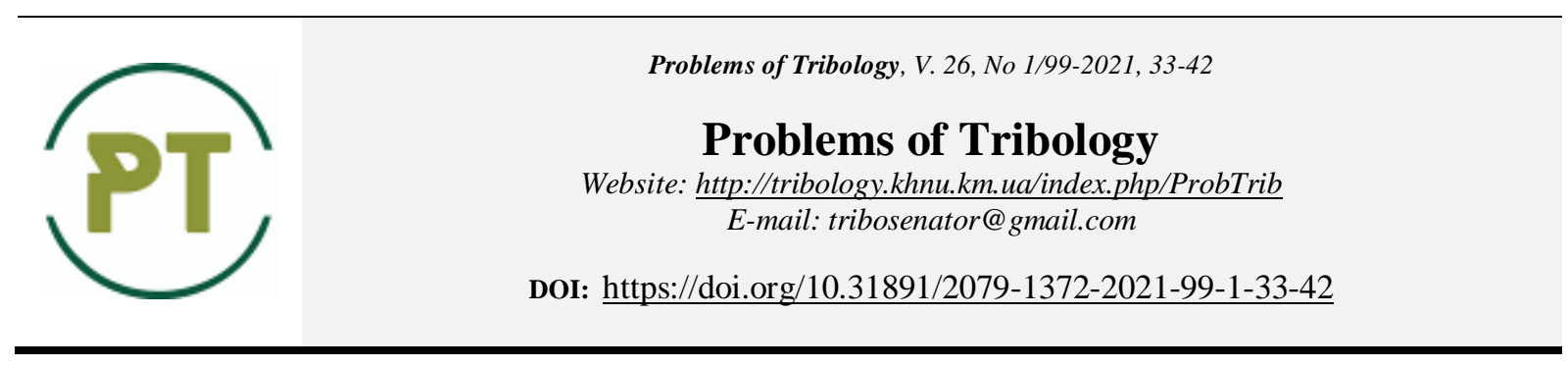

\title{
Research of tribotechnical properties of antifriction polymer compositions
}

\author{
R. M. Ostapenko \\ National University of Life and Environmental Sciences, Kyiv, Ukraine \\ E-mail: romaostapenko1504@gmail.com
}

\begin{abstract}
The analysis of antifriction polymer compositions on the basis of polyamide, epoxy, phenol-formaldehyde, furan resins, and also on the basis of fluoroplastic with various fillers working in friction knots is made. The influence of fillers on the mechanisms of friction is little studied, so when creating antifriction compositions capable of working in conditions of lubrication in water, the following tasks were set: to justify the number and type of fillers; to investigate the influence of fillers on the process of wear of material and counterbody; determine the optimal composition of the antifriction composition that provides minimal wear of the coating and the counterbody. The object of study were: compositions based on phenol-formaldehyde resin and fluoroplastic, modified with antifriction fillers; details of submersible pumps. The basis of the study was the study of tribotechnical and technological properties of polymer compositions. Based on the analysis of literature data, the target fillers for the creation of antifriction compositions for radial plain bearings and thrust bearings of submersible pumps are selected, their number and composition are substantiated. The criterion for optimization was the mass wear of the polymer coating and the counterbody. The optimal composition of the antifriction composition for radial plain bearings, which contains: a mixture of colloidal graphite $\mathrm{Cl}$ and carbon fabric "TGN-2M"; molybdenum disulfide DM-1; powder polyamide 12 APN-B; crushed prepreg comprising a fiberglass filler impregnated with a modified phenol-formaldehyde resin P2M. For thrust bearings, the optimal composition of the fluoroplastic composition is determined, which includes: fluoroplastic F4; molybdenum disulfide; carbon fabric; powdered copper. The physical and mechanical properties of the optimal composition are presented. Technological equipment has been developed for the restoration and manufacture of plain bearings and submersible pump bearings. Molds are made for industrial implementation.
\end{abstract}

Key words: plain bearings, thrust bearings, submersible pump, antifriction fillers, fluoroplastic, phenolformaldehyde resin, mold

\section{Introduction and problem statement}

The use of antifriction compositions used in the restoration of parts, allows in many cases to increase the service life of machines and reduce repair costs. This is due to the relatively low coefficient of friction of polymeric materials containing various antifriction fillers. When creating new composite materials, the selection of the most effective types of fillers is of paramount importance. However, it is known that, depending on the operating conditions, the same fillers, or a combination thereof, affect the intensity of wear of friction pairs. Currently, there is no scientifically based theory for the choice of composition and amount of fillers when creating compositions for specific operating conditions. The influence of fillers on the mechanisms of friction is little studied. Therefore, when creating antifriction compositions capable of working in conditions of lubrication in water, the following tasks were set:

a) justify the number and type of fillers;

b) to investigate the influence of fillers on the process of wear of material and counterbody;

c) determine the optimal composition of the antifriction composition that provides minimal wear of the coating and the counterbody. 


\section{Analysis of antifriction materials}

Coatings based on polyamide resins, such as polycaproamide PKA, caprolon B, polyamides P-68, AK-7, P-12L, ATM-2, aromatic polyamide (phenylene), FM-50, etc. are used to restore parts of agricultural machinery. [1]. Where the requirements for mechanical couplings are higher in terms of mechanical strength, rigidity, wear resistance at high temperatures, glass-filled polyamide with a fiber content of up to $30 \ldots 45 \%$ is used. According to BD Voronkova [2] glass-filled polyamides P-6VS, P-6VSU with a fiber content of up to $30 \%$ are used in friction units at high loads. But along with the advantages of polyamide bearings and coatings have a number of disadvantages, which include: low thermal conductivity; high shrinkage, etc. Under normal atmospheric conditions, polyamide bearings contain up to $3.5 \%$ moisture, which leads to a change in their size. With each percentage of absorbed moisture, the linear dimensions change by $0.15 \ldots 0.27 \%$. This is a significant disadvantage of polyamides, as during operation the dimensions of the bearings must be stable. Carbon-graphite and carbon-plastic are used in various friction joints antifriction materials: AMC-1; AMC-3; AF-3T; graphite plastic DEZ; AG-1500-C0.5; antiglimite (ATM); ATM-1G; DFG-2 and others, which are based on epoxysilicon-organic, phenol-formaldehyde and furan resins [3,4]. These materials are used in friction units, where the specific loads do not exceed 2.5 MPa. The increase in loads leads to an increase in the coefficient of friction and a decrease in wear resistance. Antifriction materials based on epoxy resins have become widespread in repair production. On the basis of epoxy resin ED-5 antifriction Epoxy-based antifriction material was developed "epoxylite" plasticized with debutyl phthalate and filled with graphite, bronze chips, etc. On the basis of epoxy resin ED-6, an antifriction material "maslyanite" was developed, which contains MK-8 lubricant as a modifier and aluminum powder as a filler [5,6]. Insufficiently high mechanical properties, low operating temperatures, high coefficient of friction constrain the widespread introduction of epoxy compositions. Under conditions of limited lubrication, high wear resistance was shown by textolites based on resol phenol-formaldehyde resin. From antifriction textolites working in friction units are known: PTK-C; PTG-1 [7], the main advantages of which are stable operation under conditions of high compressive loads. Such requirements are met by compositions based on thermosetting phenol-formaldehyde resins, which can be used in Supervisor Ruzhilo ZV, Ph.D., Associate Professor (NULES), Kyiv. The production of coatings for the restoration and manufacture of bearingsECV. This polymer antifriction composition contains: as a binder - crushed prepreg, which consists of bakelite varnish and fiberglass in a ratio of 1: 1.6; molybdenum disulfide; a mixture of colloidal graphite and carbon fabric in a ratio of 1: 1 and powdered polyamide [8]. Compositions based on fluoroplastic (PTFE) have higher wear resistance. In its pure form, fluoroplastics as antifriction materials should not be used due to insufficient wear resistance, cold flow, low thermal conductivity and high coefficient of linear expansion. Composites are widely used for plain bearings, piston pumps: Ф4K20; FN-202; FCN-7 (14); AFGM-5 (10); Ф40M30; Ф40С15M1,5; Ф40Б20; FKM-80VS; graphite plastic KV, 7V-2A; flubon-10 (15, 20) and others. $[3,9,10]$. PTFE compositions with glass fillers (filler content from 5 to $40 \%$ ) are produced in a wide range of branded products from the United States, Western Europe and Japan. The composition of the filler (fiber, dispersed particles) is not always specified by firms. Most often, glass fiber (SV) with a fiber length of $10 \div 15$ $\mu \mathrm{m}$ is used for compounding PTFE. The firm "Du Pont" uses ground JI (type E) with a diameter of $13 \mu \mathrm{m}$, a length of $800 \mu \mathrm{m}$, the firm "Hoechst" - with a diameter of $10 \mu \mathrm{m}$, a length of 50-100 $\mu \mathrm{m}$ [11]. Glass-filled PTFE is used for the manufacture of bearings, gaskets, non-lubricating compressor rings, valve seats, insulation for work in the chemical industry, electrical engineering and mechanical engineering. These parts can be operated at temperatures from -267 to $+260^{\circ} \mathrm{C}$, in liquid oxygen and sulfuric acid. They have advantages over unfilled PTFE: increased thermal conductivity; durability; dimensional stability and reduced cold flow. Known compositions of PTFE with metals, oxides and salts of metals, alloys, synthetic ceramics. The most common are PTFE compositions with bronze, as well as with a mixture of bronze, graphite and molybdenum disulfide. Firms use spherical and irregular dendritic bronze (particle size less than $60 \mu \mathrm{m}$ ). The ratio of copper to tin in this bronze is 9: 1 [9]. PTFE filled with bronze is characterized by the highest wear resistance during dry friction. At high-speed friction for better heat dissipation, it is advisable to add to the composition of graphite or carbon fiber. Fluoroplastic compositions can be effectively used when applying coolant to the friction zone. For example, the coefficient of friction without lubrication on steel X18H9T at a sliding speed of $1 \mathrm{~m} / \mathrm{s}$ for such compositions as $\Phi 40 \mathrm{M} 30, \Phi 40$ is $0.6 \ldots 0.66$, when lubricated with water it decreases to 0.036 ... 0.06 [6]. For thrust pump bearings, it is advisable to use compositions based on fluoroplastic with the following fillers: carbon fabric; molybdenum disulfide; powdered copper [12]. Porous compositions based on fluoroplastic increase elasticity, dampen vibrations, provide lubrication to the friction zone (due to "pockets") [13,14]. Submersible pumps operate in conditions of high vibration, especially at start-up. Therefore, in these pumps it is advisable to use double-layer damping bearings, which are covered with a layer of polyurethane in outer diameter [15].

\section{Research methodology}

The object of study were: compositions based on phenol-formaldehyde resin and fluoroplastic, modified with antifriction fillers [8,12]; details of submersible pumps, including deep groove ball bearings and thrust bearings. The basis of the study was the study of tribotechnical and technological properties of polymer 
compositions. The study was performed on an experimental setup (fig. 1), created on the basis of a hydraulic press PSU-250.The PSU-250 press belongs to type of hydraulic with a torsion silt gauge.

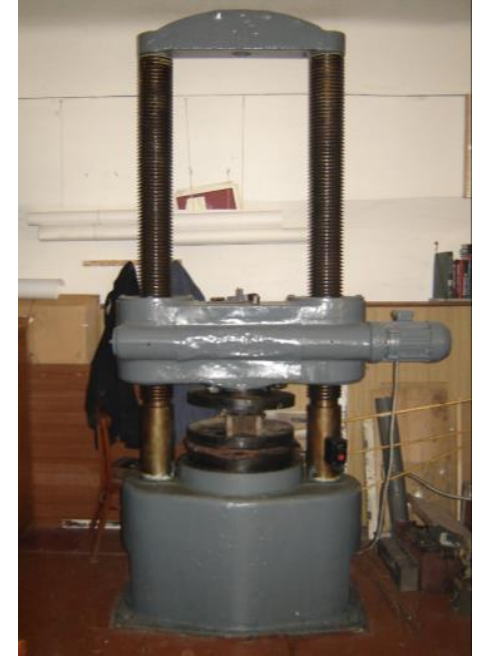

Fig. 1. Hydraulic press PSU-250: Technical characteristics of the press: the maximum admissible loading at compression - 250 ts .; number of measuring ranges 2; limits of measurement of ranges: the first 25 ... 100 ts .; $50 \ldots 250$ ts .; the largest stroke of the piston is $50 \mathrm{~mm}$; speed of movement of the working piston $-0 .$. $20 \mathrm{~mm} / \mathrm{min}$.; the greatest distance between basic plates is $800 \mathrm{~mm}$; the size of the base plate is $440 \times 440 \mathrm{~mm}$.

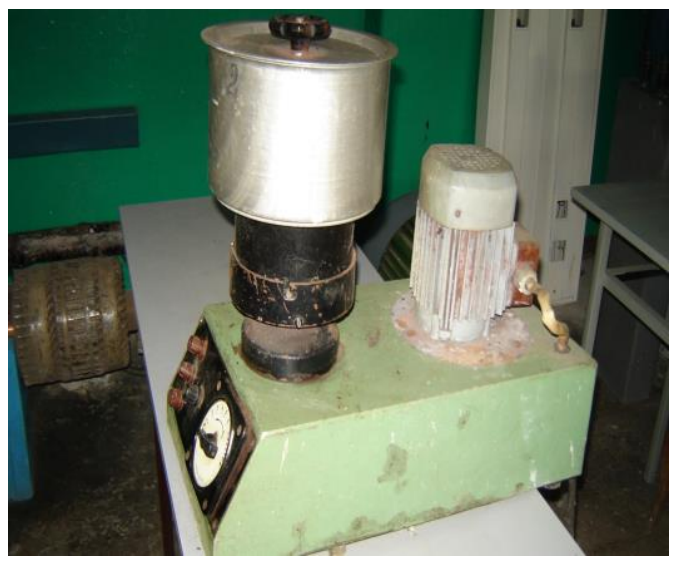

Fig.2. Mill MPR-2 :Technical characteristics: Productivity, samples / hour - 10; Grinding time of one sample, min-3; Mass of samples, Mr -100; Voltage, at 380; Power, kW - 0.6; Speed, rpm -7000

For mixing and grinding of components used mill MPR-2 (fig. 2) is designed for grinding dry materials with a moisture content of not more than $14 \%$ with particles of $40 \mathrm{~mm}$ in the largest size. Sintering of blanks from fluoroplastic compositions was performed at a temperature of $380{ }^{\circ} \mathrm{C} \pm 5^{\circ} \mathrm{C}$ in the furnace SSHO-3.2 (fig. 3). Temperature regulation from $20{ }^{\circ} \mathrm{C}$ to $380{ }^{\circ} \mathrm{C}$ was carried out by changing the power output through an autotransformer, and the voltage and power of the thermoelectric installation were measured by the device NK50 , which included an ammeter, voltmeter and wattmeter.

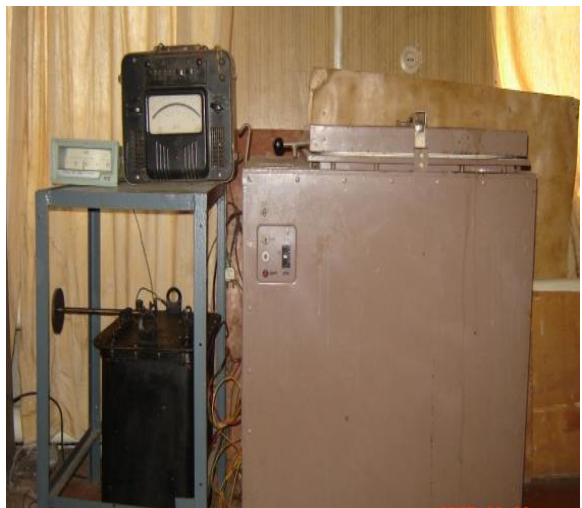

Fig.3 Electric furnace SSHO-3, Technical characteristics: Voltage, at 220; Power, kW- 6; Nominal temperature, ${ }^{\circ} \mathrm{C}-380$

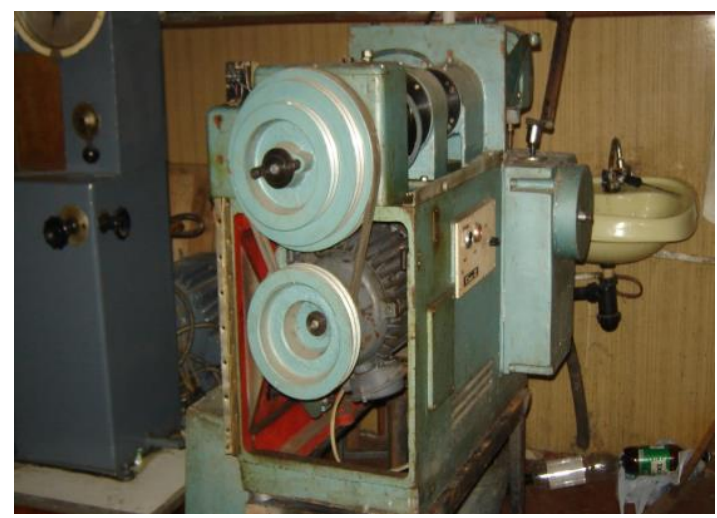

Fig.4 Friction machine SMC-2

Laboratory studies to determine the intensity of wear and the coefficient of friction were performed on a friction machine SMC-2 (fig. 4), and to determine the moment of friction used a special strain gauge [16]. The design of the device (fig. 5) provides the ability to determine the moment of friction directly from the movement of the pad, which is fixed on a digital strain gauge IDC-1. The wear resistance of the test compositions was determined according to the "pad-shaft" scheme. The experiments were performed at a sliding speed of $4.0 \mathrm{~m} / \mathrm{s}$ and a load of $1.5 \mathrm{MPa}$ (lubrication with water). The coating was applied to the inner surface of the sleeve with a diameter of $40 \mathrm{~mm}$, a length of $10 \mathrm{~mm}$, a coating thickness of $1 \mathrm{~mm}$. Sectors with a cross-sectional area of $2 \mathrm{~cm} 2$ were cut from the bushings (fig. 6). To determine the wear resistance as a counterbody used samples made of steel $40 \mathrm{X} 13$, brake-treated to a hardness of HRC $42 \ldots 45$. 
The magnitude of the operation of the samples was determined by weighing to the nearest $0.1 \mathrm{mg}$ on a laboratory scale of the second class of the model VLR-200 for 10 hours of continuous operation.

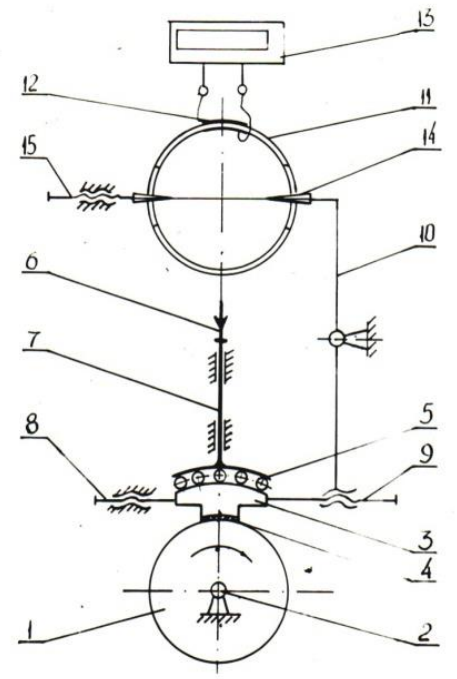

Fig. 5. General view of the strain gauge device for determining the moment of friction: 1 - counter body; 2 shaft; 3 - pad; wear resistance; 4 - polymer coating; 5 rolling bearing; 6 - cargo; 7 - carriage; 6,9 - adjustable screws; 10 - the lever; 11 - power meter;12 - strain gauges; 13- deformation meter; 14.15 -strings

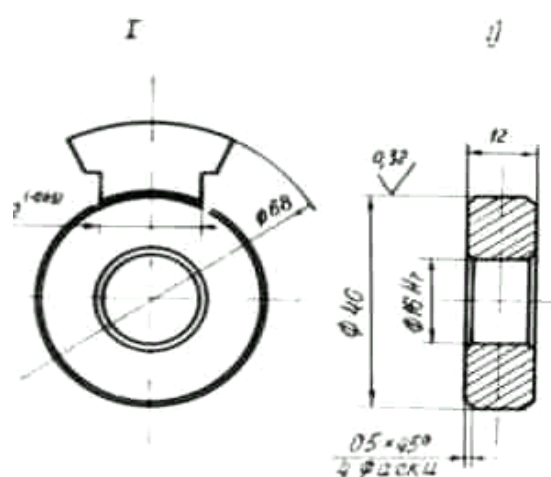

Fig.6 Sketches of samples for research

\section{Presentation of research materials}

At the first stage of research, the optimal composition of the composition for radial plain bearings of electric submersible pumps based on phenol-formaldehyde resin was determined.

The second determined the optimal composition of the polymer composition for the thrust bearings of the electric motor of submersible pumps based on fluoroplastic.

The parameters of optimization were mass wear.

Optimization of the composition of the polymer composition based on phenol-formaldehyde resin for radial plain bearings of the electric pump.

Preparation of antifriction compositions for plain bearings includes the following operations:

-grinding of high-strength fiberglass polymer AG-4V (GOST 20437-75) and sifting it through sieves with different hole sizes. After sieving, the composition of the polymer fraction was: up to $50 \mu \mathrm{m}$ - not more than $10 \%$; up to 150 microns - no more than $15 \%$; up to 400 microns - no more than $55 \%$; up to 500 microns - no more than $20 \%$;

-mixing the prescription amount of crushed prepreg, a mixture of colloidal graphite and carbon fabric, molybdenum disulfide and polyamide powder for 10 minutes;

-coating of compositions by compression pressing in modes: pressing pressure $60 \mathrm{MPa}$; mold temperature $165^{\circ} \mathrm{C}$; exposure time under pressure $-0.8 \mathrm{~min} / \mathrm{mm}$ thick.

As antifriction fillers are taken: molybdenum disulfide DM-1; a mixture of colloidal graphite C-1 and carbon fabric TGN-2M and powdered polyamide 12 APN-B [8 ].

When creating an antifriction composition, we selected the levels of variation of fillers (table 1).

Table 1

Levels of variation of factors

\begin{tabular}{|c|c|c|c|}
\hline \multirow[t]{2}{*}{ The value of the factor } & \multicolumn{3}{|c|}{ Code value of levels } \\
\hline & -1 & 0 & +1 \\
\hline $\begin{array}{l}X_{1-} \text { a mixture of graphite } \mathrm{C}-1 \text { and carbon fabric TGN- } \\
\qquad 2 \mathrm{M}(1: 1)\end{array}$ & 0 & 8 & 16 \\
\hline$X_{2-}$ molybdenum disulfide DM-1 & 0 & 2 & 4 \\
\hline$X_{3--}$ powder polyamide 12 APN-B & 0 & 7 & 14 \\
\hline
\end{tabular}


The criterion for optimization was the mass wear of the polymer coating (Y1) and the counterbody (Y2). When optimizing the composition of the composition varied the content of a mixture of colloidal graphite and carbon fabric (X1), molybdenum disulfide (X2), powdered polyamide (X3) with a constant content of crushed prepreg, including a mixture of fiberglass and modified phenol-formaldehyde resin P2M. To obtain a mathematical model of the optimum zone, a second-order plan (Box-Benkin) was used, consisting of 15 experiments (table 2) and including three points, which are fixed at zero.

Table 2

Planning matrix and results of experiments to determine the wear of the polymer coating and counterbody.

\begin{tabular}{|c|c|c|c|c|c|}
\hline № experience & $X_{1}$ & $X_{2}$ & $X_{3}$ & $Y_{1}$ & $Y_{2}$ \\
\hline 1 & 16 & 4 & 7 & 3,0 & 1,9 \\
\hline 2 & 16 & 0 & 7 & 3,3 & 3,2 \\
\hline 3 & 0 & 4 & 7 & 4,6 & 2,4 \\
\hline 4 & 0 & 2 & 7 & 5,3 & 3,8 \\
\hline 5 & 16 & 2 & 0 & 2,9 & 2,6 \\
\hline 6 & 16 & 2 & 14 & 3,2 & 3,3 \\
\hline 7 & 0 & 2 & 0 & 5,2 & 2,8 \\
\hline 8 & 0 & 4 & 0 & 1,9 & 4,2 \\
\hline 9 & 8 & 4 & 14 & 2,4 & 1,8 \\
\hline 10 & 8 & 0 & 0 & 3,0 & 3,0 \\
\hline 11 & 8 & 0 & 7 & 3,8 & 2,2 \\
\hline 12 & 8 & 2 & 7 & 2,3 & 4,0 \\
\hline 13 & 8 & 2 & 7 & 1,8 & 2,0 \\
\hline 14 & 8 & 2 & 2,1 & 2,2 \\
\hline 15 & 8 & 2 & 14 & 1,7 \\
\hline
\end{tabular}

As a result of calculation of coefficients of the equations received initial model of the following kind:

$$
\begin{aligned}
& y_{1}=2,06-0,85 X_{1}-0,44 X_{2}-0,31 X_{3}+1,53 X_{1}^{2}+ \\
& +0,53 X_{2}^{2}+0,23 X_{3}^{2}+0,1 X_{12}+0,15 X_{13}+0,075 X_{23} \\
& y_{2}=2,03-0,275 X_{1}-0,51 X_{2}-0,73 X_{3}+0,705 X_{1}^{2}+ \\
& +0,08 X_{2}^{2}+0,60 X_{3}^{2}+0,025 X_{12}+0,175 X_{13}+0,15 X_{23}
\end{aligned}
$$

Regression analysis of the model allowed to select significant coefficients from the initial model and reject insignificant ones, as well as to check the adequacy of the model.

As a result of mathematical processing of experimental researches the mathematical models which adequately describe influence of structure of fillers on wear of a covering and a counterbody are received.

$$
\begin{aligned}
& y_{1}=2,06-0,85 X_{1}-0,44 X_{2}-0,31 X_{3}+1,53 X_{1}^{2}+0,53 X_{2}^{2} \\
& y_{2}=2,03-0,28 X_{1}-0,51 X_{2}-0,73 X_{3}+0,7 X_{1}^{2}+0,6 X_{3}^{2}
\end{aligned}
$$

Analysis of regression coefficients proves that a mixture of colloidal graphite and carbon fabric, molybdenum disulfide and polyamide powder reduces the wear of both the polymer coating and the counterbody (coefficients at X1, X2, X3 are negative). Colloidal graphite has a stronger effect on reducing the wear of the polymer coating $(-0.85 \mathrm{X} 1)$ and has little effect on the wear of the counterbody. Powdered polyamide, on the contrary, has a stronger effect on reducing the wear of the counterbody $(-0.73 \mathrm{X} 3)$ and has little effect on the wear of the polymer coating. This is probably due to the fact that polyamide in comparison with graphite has a lower mechanical strength and hardness. The effect of the same molybdenum disulfide (X2) on the wear of the polymer coating and the counterbody is approximately equivalent $(-0.44 \mathrm{X} 2 ;-0.51 \mathrm{X} 2)$.

The obtained dependences $\mathrm{Y} 1(\mathrm{X} 1, \mathrm{X} 2, \mathrm{X} 3)$ and $\mathrm{Y} 2(\mathrm{X} 1, \mathrm{X} 2, \mathrm{X} 3)$ were optimized for minimal wear of the friction surfaces. The dependences $\mathrm{Y} 1$ and $\mathrm{Y} 2$ are arranged in such a way that to study the extreme properties the problem is reduced to the study of the functions of two variables. This follows from the fact that for both $\mathrm{Y} 1$ and Y2 quadratic forms can be distinguished only for two variables, for the third variable both functions decrease linearly.

Define the line of extrema Y1:

$$
\frac{\partial Y_{1}}{\partial X_{1}}=2 \cdot 1,53\left(X_{1}-0,278\right)=0
$$




$$
\begin{aligned}
& \frac{\partial Y_{1}}{\partial X_{2}}=2 \cdot 0,53\left(X_{2}-0,415\right)=0 \\
& \frac{\partial Y_{1}}{\partial X_{3}}=-0,31
\end{aligned}
$$

$\mathrm{X} 1=0.278, \mathrm{X} 2=0.415, \mathrm{X} 3$ is arbitrary. Since the quadratic shape of $\mathrm{X} 1$ and $\mathrm{X} 2$ is positive, along the line $\mathrm{Y} 1$ $(\mathrm{X} 3)=1.85-0.31 \mathrm{X} 3$ is a sliding down minimum

Similarly, we study Y2:

$$
\begin{aligned}
& \frac{\partial Y_{2}}{\partial X_{1}}=-0,28+1,4 X_{1}=0 \\
& \frac{\partial Y_{2}}{\partial X_{2}}=-0,51 \\
& \frac{\partial Y_{2}}{\partial X_{3}}=-0,73+1,2 X_{3}=0
\end{aligned}
$$

$\mathrm{X} 1=0.2, \mathrm{X} 3=0.608, \mathrm{X} 2$ is arbitrary. $\mathrm{Y} 2(\mathrm{X} 2)=1,782-0,51 \mathrm{X} 2$.

The optimal value of $\mathrm{X} 1$ for the minimum wear of the coating (Y1) and counterbody (Y2) is 0.278 and 0.200 , which corresponds to $10.25 \%$ and $9.65 \%$ of the mixture of graphite and fiber, ie the final conclusions on the results of research should be made at stabilization $\mathrm{X} 1=0,25=10 \%$ mixture of graphite and fiber.

Substituting the value of $\mathrm{X} 1=0.25$ in equations ( 3 and 4 ) we obtain:

$$
\begin{aligned}
& y_{1}=1,94-0,44 X_{2}-0,31 X_{3}-0,53 X_{2}^{2} \\
& y_{2}=2,0-0,51 X_{2}-0,73 X_{3}+0,6 X_{3}^{2}
\end{aligned}
$$

According to equations (11 and 12), the surfaces of equal response of the wear process of the polymer coating and the counterbody are constructed (fig. 7).

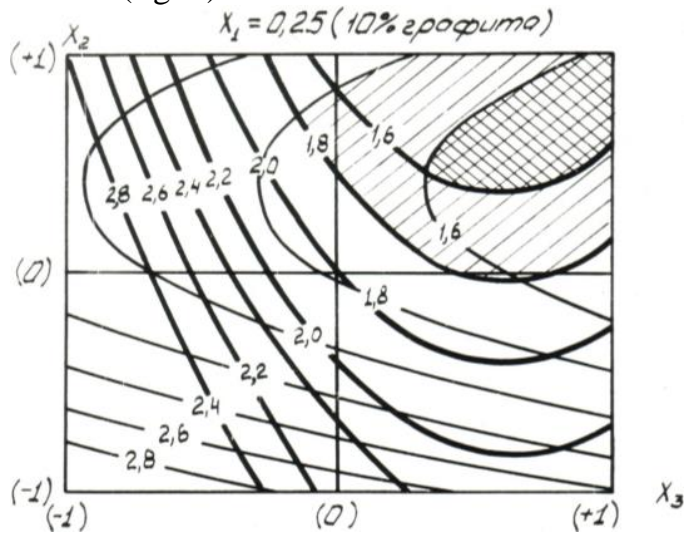

Fig. 7. Geometric image of the surface of the equal response of the wear process of the polymer coating and the counterbody

The shaded surface, limited by the isolines obtained in the calculation for the wear of the polymer coating and the counterweight equal to $1.6 \mathrm{mg}$, is optimal for determining the composition of antifriction fillers. However, previous studies have shown that when the increase in the composition of the content of powdered polyamide more than $10 \%$ leads to increased adhesion of the polymer coating to the mold surface.

To obtain a quality coating, it is necessary to cool the mold, which significantly affects the productivity of the molding process. Therefore, the optimum zone should be moved to the point of intersection of the isolines obtained for wear of $1.6 \mathrm{mg}$. At this point, the content of powdered polyamide $12 \mathrm{APN}-\mathrm{B}$ is $9 \%$, and molybdenum disulfide DM-1 - 3\%.

Since in the studied compositions the content of crushed prepreg, including fiberglass filler, was unchanged $(83 \%)$, in terms of $100 \%$ by weight of the composition, the optimal content of antifriction fillers will be: a mixture of colloidal graphite and carbon fiber - $9.5 \%$; molybdenum disulfide $-2.9 \%$; powdered polyamide 8.6\%; crushed prepreg comprising a fiberglass filler impregnated with a modified phenol-formaldehyde resin $\mathrm{P} 2 \mathrm{M}$ - the rest.

To restore the radial plain bearings thermosetting antifriction compositions used a universal mold (fig. 8) 


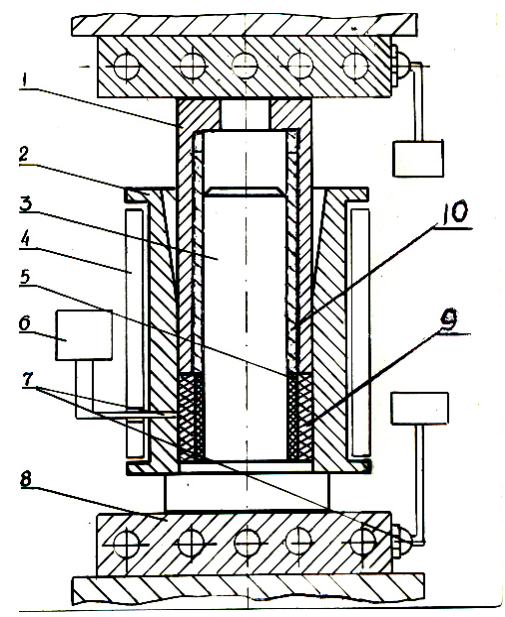

Fig.8 Scheme of a universal mold for restoring the inner diameter of plain bearings: a) thermosetting compositions; b) compositions based on fluoroplastic; c) coating the outer diameter with polyurethane (9). 1. sleeve, 2 - matrix, 3 sign, 4 - matrix heater, 5 - primer composition, 6 - milliammeter, 7 - thermocouple, 8 - heater, 9 - outer sleeve made of stainless steel (polyurethane), 10 - punch.

Restored bearings are shown in figure 9.

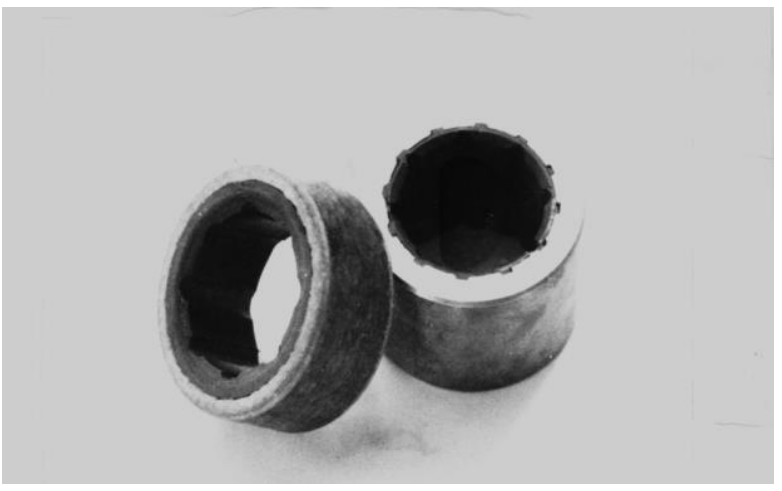

Fig.9 Restoration of the inner diameter of the radial bearing slip

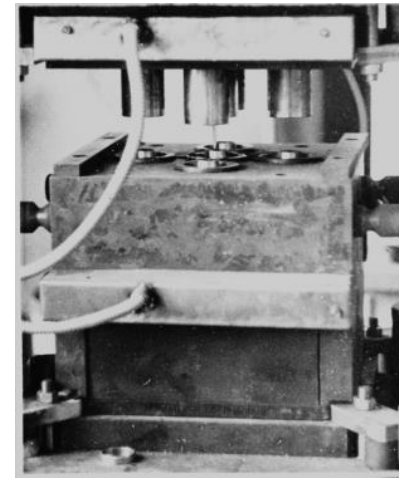

Fig.10. Five-seat mold for the restoration of plain bearings

For the industrial restoration of plain bearings made a five-seater mold (fig. 10). Development of compositions based on fluoroplastic F4 for thrust bearings. For antifriction polymer composition based on fluoroplastic F4 were taken the following components: polytetrafluoroethylene GOST 10007-78; carbon fabric TGN-2M (pre-shredded); powder copper PMS-1; molybdenum disulfide DM-1 [12 ]. A standard second-order rotatable plan was used for the study. The composition of the antifriction composition for thrust bearings was optimized by estimating the wear intensity and friction coefficient. After excluding insignificant coefficients, the following polynomial dependences of wear intensity I and friction coefficient $f$ on three factors were obtained: the composition of molybdenum disulfide $(\mathrm{X})$; carbon fabric $(\mathrm{Y})$; powdered copper $(\mathrm{Z})$. The dependence of wear intensity $(\mathrm{J} \times 10-10)$ has the form:

$$
\begin{aligned}
& I=0,5234-0,0208 \mathrm{X}+0,3315 \mathrm{Z}+0,1984 \mathrm{X}^{2}+ \\
& +0,2053 \mathrm{Y}^{2}+1,1128 \mathrm{Z}^{2}-0,0075 \mathrm{XY}+0,03 \mathrm{YZ}-0,075 \mathrm{X} \mathrm{Z}
\end{aligned}
$$

The dependence of the coefficient of friction has the form

$$
\begin{gathered}
f=0,0314-0,0005 \mathrm{X}+0,0025 \mathrm{Y}+0,01322 \mathrm{Z}+0,0072 \mathrm{X}^{2}+ \\
+0,0089 \mathrm{Y}^{2}+0,0465 \mathrm{Z}^{2}-0,002 \mathrm{X} \mathrm{Y}-0,001 \mathrm{YZ}-0,0015 \mathrm{ZX}
\end{gathered}
$$

Testing of the statistical hypothesis, made by Fisher's test, showed the adequacy of the regression model on the response function at a significance level of $\alpha=0.05$. Analysis of equations $(13,14)$ and the results of research revealed that the optimal composition, wt. h. Fluoroplastic F4 - 100. Molybdenum disulfide - 3.7 ... 3.9. Carbon fabric - 7.5... 9.4. Powder copper PMS-1 - 140.. 160. With the optimal composition of the composition, the coefficient of friction is equal to 0.032 , the wear intensity of $0.52 \cdot 10-10$ (fig. 11,12 ). 


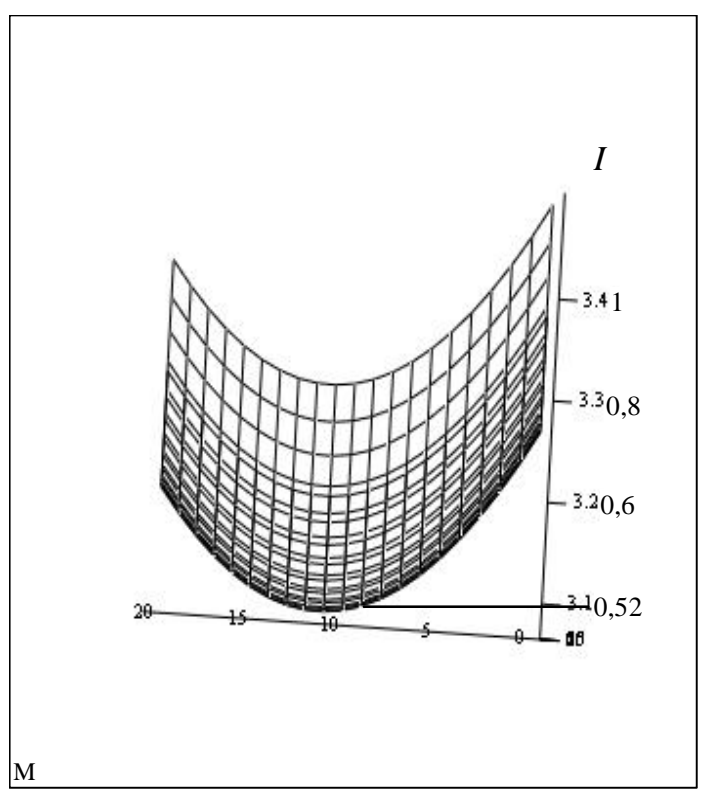

a

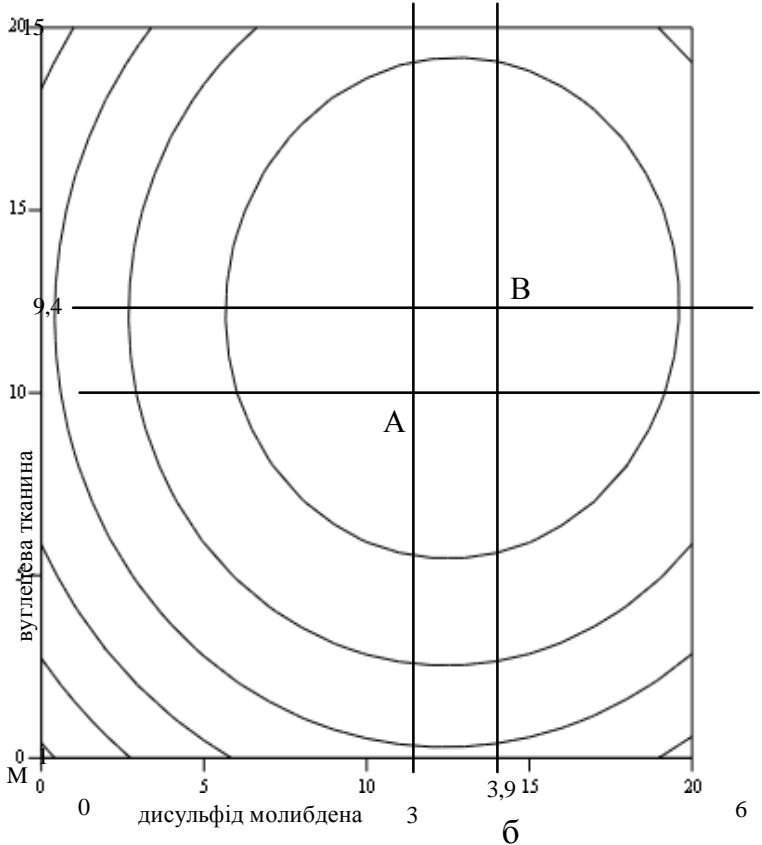

6

Fig. 11 - Graphical interpretation of the mathematical model of wear intensity (a) and two-dimensional section of the function $\mathbf{f}(\mathrm{Xi}, \mathrm{Yi}, \mathrm{Zi})$ at $\mathrm{Zk}=\mathbf{0}$.

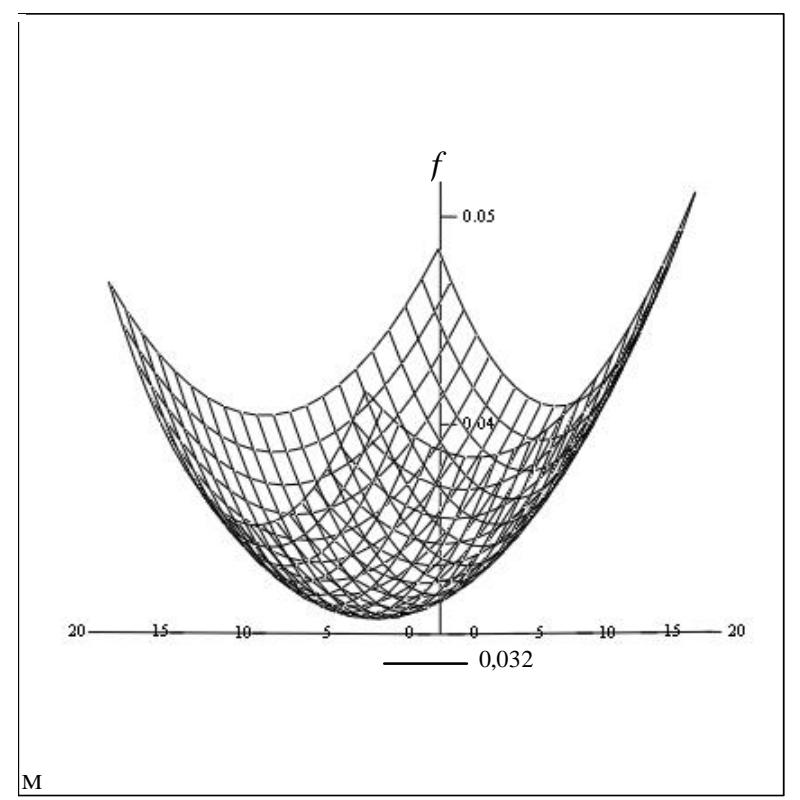

a

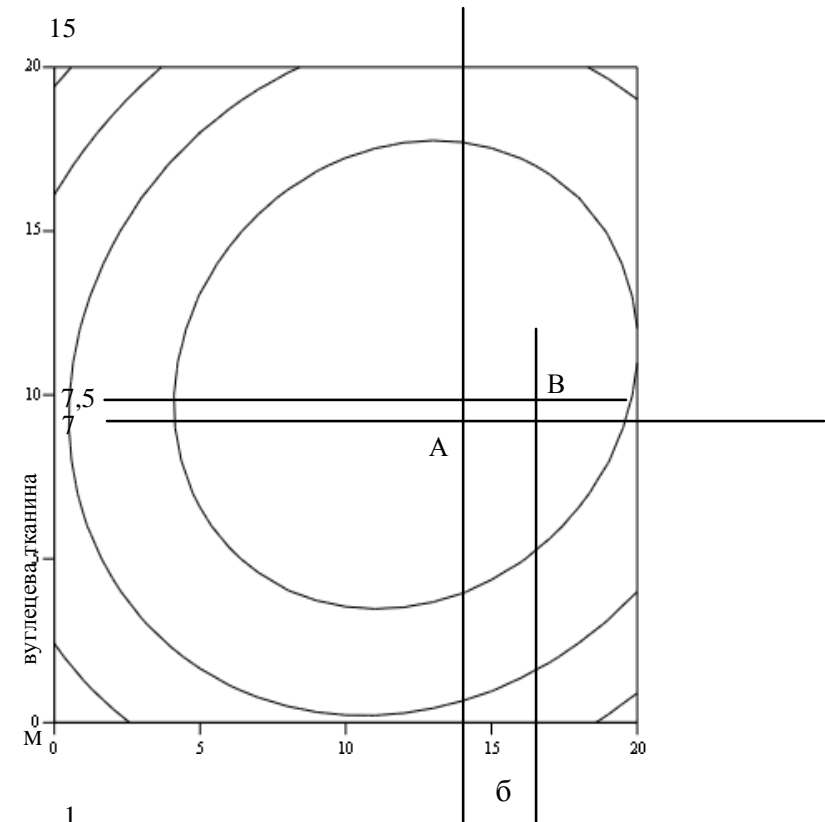

Fig. 12. Graphical interpretation of the mathematical model of the coefffrectent of friction (a) and tw6.7dimensional section (b) of the function $\mathrm{f}(\mathrm{X} 1, \mathrm{Y} 1, \mathrm{Z1})$ at $\mathrm{Z \kappa}=\mathrm{O}$

Figure 13 shows the thrust bearings of electric submersible pumps.

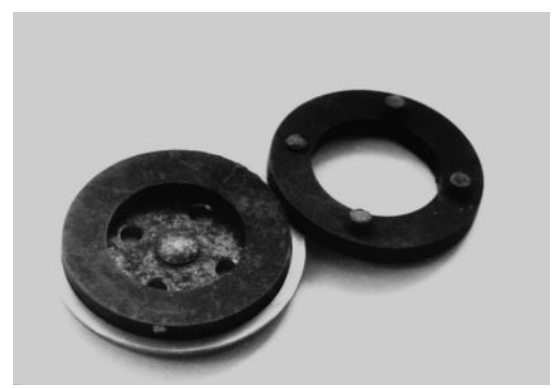

Fig.13. Billets for the thrust of the electric motor of the pump. 
Technical characteristics of the optimal composition for thrust bearings are presented in table 3.

Characteristics of antifriction material

\begin{tabular}{|l|c|}
\hline \multicolumn{1}{|c|}{ Properties of the composition } & Parameters \\
\hline Density, $\mathrm{kg} / \mathrm{m} 3$ & $3600-3700$ \\
\hline Thermal conductivity, W / mK & $0,80-1,02$ \\
\hline Coefficient of friction & $0,02-0,09$ \\
\hline Operating temperature, 0C & від -60 до +250 \\
\hline Maximum specific load, MPa & від 1 до 8 \\
\hline
\end{tabular}

\section{Conclusions}

1. Based on the analysis of the literature data, the target fillers are selected to create antifriction compositions for radial plain bearings and thrust bearings for submersible pumps.

2. The obtained regression equations that adequately describe the process of wear of the polymer coating and the counterbody. It was found that a mixture of colloidal graphite CI and carbon fabric helps to reduce wear polymer coating, and powder polyamide 12 APN-B has a stronger effect on reducing the wear of the counterbody. The effect of molybdenum disulfide on the wear of the coating and the counterbody is equivalent.

3. The obtained equations, which allowed to graphically represent the surface of the equal response of the wear process of the polymer composition for plain bearings of electric submersible pumps, which determined the optimum zone of antifriction fillers:

a) a mixture of colloidal graphite $\mathrm{Cl}$ and carbon fabric $\mathrm{THN}-2 \mathrm{M} 9.5 \%$

b) molybdenum disulfide DM-1 $2.9 \%$

c) powder polyamide 12 APN-B $8.6 \%$

d) crushed prepreg comprising a fiberglass filler,

impregnated with modified phenol-formaldehyde resin P2M the rest.

\section{References}

1. Trenie i iznos materialov na osnove polimerov. V.A.Belyj, .A.I.Sviridenok.,M.I.Petroeovec,V.G.Savkin - Minsk.:Nauka i tekhnika, 1976, 432 s.

2. Voronkov V.D.Podshipniki suhogo treniya. -L.: Mashinostroenie, 1979. - 224 s.

3. Tribotekhnicheskie svojstva antifrikcionnyh samosmazyvayushchihsya plastmass / Pod red. Salagaeva G.V., SHembel' N.L. - M.: Izdatel'stvo standartov, 1992.-64s.

4.Fel'dman D.I, Gejman YU.P., Volodarskij I.A. Antifrikcionnyj material «grafitoplast DEZ» i opyt ego primeneniya. - L., 1967.-21 s.

5. Evdokimov YU.A., Barsukov R.H. Novye antifrikcionnye polimernye kompozicii, izgotovlennye na baze epoksidnyh smol.- Rostovskoe knizhnoe izdanie, 1976. - $80 \mathrm{~s}$.

6. Fel'dman D.I. Antifrikcionnyj material «Epoksilit». -L., 1966.- 16 s.

7.Gorohovskij G.A.. Primenenie polimerov dlya povysheniya protivozadirochnyh svojstv stal'nyh povekhnostej.- V kn. Trenie, smazka i iznos detalej mashin. K.,1961 s.99-107 (Trudi KIGVF, vyp. 2).

8. Dudchak V.P. Sposib vidnovlennya porshniv i antifrikcijna kompoziciya dlya jogo zdijsnennya. Pat. na vinahid Ukraïni №61442A, SO8F114/26. Zayavl. 06.02.2003. Opubl. 17.11.2003. Byul. №11.

9. Polimery v uzlah treniya mashin i priborov / Spravochnik pod red. d.t.n. A.V. CHichinadze.-M.: Mashinostroenie, 1980.-208s.

10. Sirenko G.A. Antifrikcionnye karboplastiki. .-K.: Tekhnika 1985.-195s.

11.O'Rourke J.T. Design properties of filled -TFE plastics - Machine Design, Sept. 1962.

12.Ostapenko R.M.,Ruzhilo Z.V. Dudchak T.V. ta in..« Polimerna antifrikcijna kompoziciya» Patent na korisnu model' № 136085. Byul. № 15 vid 12.08.2019.

13.Dudchak V.P., Ostapenko R.M., Dudchak T.V. Sposib oderzhannya poristoï antifrikcijnoï kompoziciï na osnovi ftoroplastu Patent na korisnu model' № 82868. Byul №16 vid 27.08.2013.

14.Dudchak V.P., Duganec V.I., Ostapenko R.M., Dudchak T.V. Sposib oderzhannya poristoï antifrikcijnoï kompoziciï. Patent na korisnu model' № 81028 Byul № 12 vid 25.06.2013.

15. Ostapenko R.M., Sandik A.M., Ruzhilo Z.V. ta in.. «Sposib vigotovlennya dvosharovogo dempfiruyuchogo pidshipnika kovzannya dlya elektrozagliblyuval'nih nasosiv» Patent na korisnu model' № 136454 27.08.2019.

16. Petrov YU.N., Dudchak V.P., Kolyasko I.V. Pribor dlya izmereniya momenta treniya podshipnikov skol'zheniya. A.s. №1223730 SSSR Opubl. 8.12.1985. Byul. №47. 
композицій

Остапенко Р.М. Дослідження триботехнічних властивостей антифрикційних полімерних

Зроблений аналіз антифрикційних полімерних композицій на основі поліамідних, епоксидних, фелолформальдегідних, фуранових смол, а також на основі фторопласту з різними наповнювачами, які працюють в вузлах тертя. Вплив наповнювачів на механізми тертя мало вивчені, тому при створенні антифрикційних композицій, здатних працювати в умовах змащення у воді, були поставлені наступні задачі: обгрунтувати кількість і тип наповнювачів; дослідити вплив наповнювачів на процес зносу матеріалу і контртіла; визначити оптимальний склад антифрикційної композиції, що забезпечує мінімальний знос покриття і контртіла.

Об'єктом дослідження були: композиції на основі фенолформальдегідної смоли і фторопласта, модифіковані антифрикційними наповнювачами; деталі заглиблювальних насосів.

Основою дослідження було вивчення триботехнічних і технологічних властивостей полімерних композицій.

На підставі аналізу літературних даних обрані цільові наповнювачі для створення антифрикційних композицій для радіальних підшипників ковзання та підп'ятників електрозаглиблювальних насосів, обгрунтовано їхню кількість і склад. Критерієм оптимізації служили масовий знос полімерного покриття і контртіла. Визначено оптимальний склад антифрикційної композиції для радіальних підшипників ковзання, який містить: суміш колоїдного графіту $\mathrm{Cl}$ та вуглецевої тканини «ТГН-2М»; дисульфід молібдену ДМ-1; порошковий поліамід 12 АПН-Б; подрібнений препрег, що включає скловолокнистий наповнювач, просочений модифікованою фенолформальдегідною смолою Р2М.

Для підпятників визначено оптимальний склад фторопластової композиції, який включає: фторопласт Ф4; дисульфід молібдену; вуглецеву тканину ; порошкову мідь. Представлені фізикомеханічні властивості оптимальної композиції.

Розроблено технологічну оснастку для відновлення і виготовлення підшипників ковзання i підп’ятників електрозаглиблювальних насосів. Виготовлені пресформи, для промислового впровадження .

Ключові слова: підшипники ковзання, підп'ятники, заглиблювальний насос, антифрикційні наповнювачі, фторопласт, фенолформальдегідна смола, пресформа. 